Research Paper

\title{
The Performance of Nandong in Simeulue Island
}

\author{
Tasnim Lubis ${ }^{1}$, Robert Sibarani ${ }^{1}$, Syahron Lubis ${ }^{1}$, Ichwan Azhari ${ }^{2}$ \\ ${ }^{1}$ Doctoral Program in Linguistics, Faculty of Cultural Sciences, Universitas Sumatera Utara, Medan, Indonesia \\ ${ }^{2}$ Faculty of Social Sciences, Universitas Negeri Medan, Medan, Indonesia \\ Corresponding Author: Tasnim Lubis
}

\begin{abstract}
Performance seizes all dimensions of language when performers produce utterance. This study is concerned with the performance of nandong oral tradition. Anthropolinguistic components of text, cotext, and context were used to describe the structure, stages, performing components, and speech function of nandong. Ethnographic method was also implied in this study. The data was based on audio-video recording, transcription, and field notes. The instrument used to record the nandong was Panasonic HC-V180 full HD handycam. The results showed that the structure of nandong is classified as poetic, and the stages of nandong (only in formal situation) consist of seuramo, nandong for opening, for content, and for closing, and seuramo again. The performing components include small and big group, and individual or solo. The speech functions of nandong were persuasive and narrative. Above all, the nandong performance is advisable and its function is to assign an "alarm" for people in Simeulue when they face their problems of living.
\end{abstract}

Keywords: Performance, nandong Simeulue, and anthropolinguistics

\section{INTRODUCTION}

Human express their idea's, thoughts, and feeling through language. A wink, pursed lips, raising eyebrow, hug and kiss are language. Seyfeddinipur dan Gullberg (2014) stated that language used is fundamnetally multimodal. Multimodal involved body movement, facial expression, face and gaze, and also gesture. All of them have meanings. They occur together with the text or without text. When a person looked away to the other(s), it could be expressed angry, or embarassed. Or when we see somebody thumbs up to his friend, it could be expressed salute. The meanings has relationship with a dealing that exist in particular social community. To express or to perform the action known as performance.

In a opera, the performer known as singer. In a magic show, the performer known as magician. In a court room, performers known as judge, lawyer, prosecutor and so forth. In a classroom, the performer is a teacher or lecturer. Their action, manner, and behaviour during the event, until using material are called performance. Or I can say a set of human action included material or equipment are perform in a same time namely performance.

Why study performance is matter? Because human is creative to express their ideas, thought, and feeling not only in literal but also nonliteral way. It is also because every sign is produced has meaning ang indexicality. Meaning and indexicality is live in a community and they will accept both verbal and nonverbal performance. Human also able to create their expression toward opposite meaning at the same time. For example when a superior angry to 
his/her subordinate. The subordinate trying to show normal face instead showing resentment. In nandong, the poems were sung through high pitch (tenor and counter tenor) by man/men to deliver the message (advice)

Each community has their own unique that reflected in their creativity. It can be represented in a building, the way of farming, and also their show. The show (performance) is represented through dancing, pantoon, poetry, drama, and etc. In Simeulue island, located about $150 \mathrm{~km}$ from west Aceh coast, there is nandong as one of oral tradition. Nandong is performed orally in delivering the message. The way of performance has specific and particular pattern and it is become a prototype. Sibarani (2018: 48) states that the study of an oral tradition focus on the unity of form, content, and the herritage in its performance and the whole improvisation in it. The chant of nandong in telling about fate of the performer (namely nandong untung) is able to make the listeners/audiences cry because come into the story.

Nandong in Simeulue deals with pantoon and poetry that is sung by man/men with high pitch. Those pantoon and poetry contain advices and stories. Nandong occures in Aneuk jamee language dominantly. Besides, there are NS in Simeuluenese local language such as Devayan, and Sigulai. In NS, the performance has meanings and values that reflected Simeulunese behaviour in common. Knowing the performance toward the formula of nandong will address to its revitalization. In this study, the researcher used linguistic anthropolinguistic approach to describe and find the formula of nandong.

Nowadays, nandong is rarely to find and young generation begin confuse to determine nandong with the another oral tradition in Simeuluenese namely tarian Andalas. Globalization and technology also takes part replacing the existance of nandong to the other modern music such as keyboard and dangdut. Formerly, nandong was one of expected occasion in wedding party. But now, they prefer keyboard instead of nandong. The nandong as a tradition, a culture and also a herritage from ancestor is worthy to be saved. The advice, stories, and the way to perform is contain of local knowledge which useful to manage their life such as how to behave and keep balancing their environment too. It should be shared and inform to the next generation in order to keep the balancing and surviving living in a small island that surrounding by Hindia ocean.

Lubis (2017) states that it is possible to study a language without knowing how they utter (produce) and the meaning of the utterance is depend on the context when the utterance is produced. So, to find out the structure, the performance is the only way to do in order to describe an oral tradition. Oral is in cultural practices. The practices consist of verbal and nonverbal. The study of oral literature, can be done through anthropolinguistic approach because it able to inform the expression in particular/specific way in a speech community

\section{MATERIALS AND METHODS}

The location was in Simeulue island, at Simeulue Timur and Teupah Barat districts. Simeulue island located on the west part of Aceh, Sumatera. It is surrounding by Hindia Ocean. There are about 147 small islands around Simeulue island. The data were recording of nandong performance, transcript of nandong, and field notes. The technique of collecting data was done by doing interview, participant observation and recording by using handycam Panasonic HC-V180 full HD. Ethnography method by Spradley $(1970,1980)$ was used in this study. The table 1 below displays the stages of sthnography method.

\section{RESULTS AND DISCUSSION}

Nandong is rely on tradition from Minangnese who move from their area to Simeulue island. Tradition occurs not accidentaly happen, but there was a history 
with it. Oral tradition has strong relationship with a culture in one social community. It means culture is occurred as a media to express and inform an event. Finnegan (2005: 86) explains that performance (oral tradition) as a specific mode of human communication and action that distinguish from their daily life. Then, a particular act from a communication is noted as performance through quality and framing. In communication, language is appeared as one of cultural resources. In addition, Sims dan Stephens (2005) stated that there are some differences in creating tradition:

Table 1. The stages of ethnographic method

\begin{tabular}{|l|l|}
\hline Interview & Participant observation \\
\hline Locating informant & Locating situation \\
\hline Doing interview & Doing participant observation \\
\hline Making ethnography method & Making ethnography method \\
\hline Making descriptive question & Making description observation \\
\hline Making interview analysis & Making domain analysis \\
\hline Making domain analysis & Making focus observatin \\
\hline Making structural question & Making taxonomic analysis \\
\hline Making taxonomi analysis & Making a selected observation \\
\hline Making contrast question & Making analysis component \\
\hline Making analysis component & Discover cultural themes \\
\hline Discover theme analysis & $\begin{array}{l}\text { Mengambil sebuah inventori } \\
\text { budaya }\end{array}$ \\
\hline Writing an ethnography & Writing an ethnography \\
\hline
\end{tabular}

\section{Proximity}

One of the stereotypically recognizable differentiators among folk groups is ethnicity, especially when it is someone else's ethnicity. One of the closest to speech community is their geography. The events of their surrounding inspire them to create their oral tradition. Formerly, most of Simeuluenese do farming and fishing as work for a living. Therefore, their nandong was created by informing what they had in their surroundings. We can see lyrics of pantoon below which describe about how they do farming and fishing:

a. Manabeh mangko berladang (to cut down then make a rice field).

b. Padi di ladang rabah mudo (young rice in the field is down).

c. Padi talatak ate pamatang (rice is on embankment).

d. Si Sabon marapek bidok (Sabon [name] close the boat).

\section{Necessity, obligation, or circumstance}

Just as proximity may automatically gain a person membership in a folk group, so may necessity, obligation, or circumstance. Each of us is born or adopted into a family from whom we learn beliefs, values, and traditions. Simeuluenese children immitate and observed what they have seen (including tradition) from their family and their surroundings. The tradition is live in their memory and it can be change dinamically.

\section{Regular interaction}

Demarcations among groups are formed as we develop our own personal identities, distinct from our families and neighbors. Such groups are usually established first by proximity, but they are reinforced through regular interaction. The existence of nandong from Minangnese who live in Simeulue, finally became one of Simeuluenese oral tradition because it is accepted in Simeuluenese. Not only nandong as "comer", but also others oral tradition from Aceh and Aceh Singkil namely tari Andalas, Rapa'i Debus, and tari Gelombang became Simeuluenese oral tradition too.

\section{Shared interests or skills}

Often, particularly distinctive types of groups are those derived from shared interests or skills. These groups may begin in places such as classrooms or offices and expand outward, taking a shape generated by their members. Sometimes, individuals may come together seeking others with common skills or interests and form a group based on those commonalities. In other cases, these groups may be preexisting, with members moving into (and out of) them somewhat fluidly. A group brought together by skill or interest becomes a folk group as it incorporates more elements of communication.

Nandong performance showed the character and identity of Simeuluenese. Bauman (1977) states that performance in formal situation reflected the matter of paying attention (so far is known as the centre of attention) that involved self 
awareness manipulation from formal features of communication system (it is displayed through physic movement in dancing, language and pitch in a song, and so forth). Performance can be seen as metacultural entirely. It means object is rely on the controll of the culture itself. Bauman also explain that Singer, an American antropolog in his study to understand the complexity culture in India, he concentrate his attention to the form of culture such as drama, consert, learning, ritual speech, and recite, rite, ceremony, and festivals. It is because from his friend (an Indian) their culture is anchored in their separated performances. Therefore, they able to perform it to the audience and also for themselves. Singer called it as "cultural performance". The meaning prefer to the context of stand out performance and to show a set of character of the community

To study about nandong as an oral tradition, anthropolinguistic approach was used. Anthropolinguistic involved interdiscipliner between anthropology dan linguistic. It study a language by using anthropology framework, study a culture by using linguistic framework and study each aspects of human life by using both anthropology and linguistic. Sibarani as linguist states that there are three component of performance. They are text, co-text and context. While, Finnegan, an anthropogist states that there are four element of performance. They are human participation, framing, organisation and situation. Human partcipation can be reflected to text and cotext. Framing can be reflected to text. Organization also reflected to text because it describe about the formula and performer component. Situation is reflected to context.

The parameter of anthropolinguistic are interconnection, valuability, and sustainability. By using anthropolinguistic, study of nandong performance not only to describe the performance, but also to evaluate the meaning, function, value, and norms toward its revitalization. Nthropolinguistic approach is a appropriate approach to study about oral tradition. The concept of performance in this study refers to every action of speaking. The actions include show, appearance, and also speech in daily conversation. Begins from folklor studies, and develop to performance studies, and now are linguistic anthropology studies. The experts such as Bauman dan Honko emphasize performance as crucial element to study of human behaviour. Bauman (2010: 60) stated that studies of performance can make a unique contribution in language studies.

As many authors have stressed, performances are not simply artful uses of language that stand apart both from day-today life and from larger questions of meaning, as a Kantian aesthetics would suggest. Performance rather provides a frame that invites critical reflection on communicative processes. A given performance is tied to a number of speech events that precede and succeed it (past performances, readings of texts, negotiations, rehearsals, gossip, reports, critiques, challenges, subsequent performances, and the like.

Then, Honko (2000: vii) explained that oral performance cannot be captured in letters and words. Too many essential features are simply left aside in the written codification of a speech event which normally employs a wide array of paralinguistic means of expression from gesture to music. The other definition came from Hymes in Duranti (1997: 15) defined performance is something creative, realized and achieved. Nandong belong to Minang (an ethnic in Sumatera located in west Sumatera). Minangnese who came to Simeulue island applied their oral tradition too. Nandong in Simeulue occure in Aneuk jamee language as Minang dialect. In Aneuk jamee language, there is sound addition for some words. Crowley dan Bowern (2010) state that besides lenition, (soundless) as a kind of different sound, it is common to find sound addition. As a whole, however, it is rarely to find sound addition, but in some context, it is exist. The table 2 below 
displayed the different between Minang and Aneuk jamee language:

Tabel 2. The different between Minang language to Aneuk Jamee language

\begin{tabular}{|l|l|l|}
\hline Minang language & Aneuk Jame language & English \\
\hline Kama & Kamano & Where \\
\hline Dima & Dimano & Where \\
\hline Ba-a & Ba-apo & How \\
\hline
\end{tabular}

Pantoons and poetry in nandong have function to deliver the advices and stories from Simeulue ancestor. The advices rely on moslem religion which tells about how to behave in facing problems in living. The stories completed by provide the their experiences. Beside advices and stories, nandong also has argumentative function to communicate. Below, we can see the pantons that display advice and story. As a text, the nandong divided into three structures; supermacro, superstructure, and microstructure. Based on these, it can be found that the genre of $N S$ is pantoon and poetry. In a bait of pantoon, two first lines are sampiran (nonliteral) and last two line are content (literal). The example of pantoon:

Anak cino manyapu sarok (Chinese kid sweeps the garbage). Dalam sarok bajampu ame (in garbage there is gold). Nan kayo janganlah arok (the richer should not be arogant). Mantang mikin janganlah same (to the poor do not underestimate)

Text (1) warned the listener (Simeuluenese) to be low profile even rich. The expression can be seen in the last two lines. The value of the expression deals with respect to each other without considering worthy, position, and others. Every human are same. Rich and poor are condition that might be changed among people. So, this pantoon teaches about good behaviour in facing different condition among people. The genre is pantoon. Next, the poetry can be seen as follows:

Enggel mon sao curito (there is a story). Inang maso semonan (once upon a time). Manoknop sao fano (the village is drowned). Uwilah da sesewan (that is the told story).
In text (2), the entire lyrics consist of content. but the spirit of advice still exist. Text (1) is in Aneuk jamee language, but in text (2) is in one of Simeuluenese local language namely Devayan. For superstructure, the performance of nandong describes the formula in formal occasion. It consists of:

Seuramo. Seuramo is beating kedang (drum) to inform that nandong will be started.

Nandong for opening. It deals with sing particular nandong that asking for opening and permission.

Nandong as the content. The performer determines nandong at this part based on the main occasion (framing), such as in wedding party, khitanan, or build a house.

Nandong for closing. Nandong for closing is not sing like nandong for opening and content. It is sung with the normal rate and faster.

Seuramo. In this part, seuramo has a meaning to inform the audience that the occasion is end.

For microstructure, nandong has persusive and narrative functions. Persuasively, nandong is encoded in imperative, invitation, and also satire. Narratively, nandong is encoded in declarative / statement. The way the penandong delivers the nandong to support the speech. It exists in penandong appearance while perform nandong known as co-text. Co-text in nandong covered verbal, procsemic, kinesic and material. The nandong is perfomed by using high pitch in the beginning. The distance between audience and penandong is depend on the situation. In formal situation, a group of penandong is sitting close to the brides in a room, and the audiences are sitting or standing outside of the group. It is sung at late night at $10 \mathrm{pm}-04 \mathrm{am}$. The duration about 6-8 hours. In nonformal situation, penandong used to perform nandong while doing their daily activities such as gardening, fishing or when grabing cloves. Kinesic covered gesture and body 
movement. In nandong, penandong(s) sit by crossing their legs and sometimes do nandong by putting their palm and put their forefinger into their ears. It refers to a moslem when perform adzan. The purpose is to produce outloud voice, so the message is able to deliver.

The materials used are kedang (drum) and violin or combination both of them. In formal situation, kedang is always used. The using of kedang are to build rousing and encouraging both penandong and audiences and also as a sign to state that nandong is going to be played. Not only in the beginning but also at the end of nandong kedang also played as a sign to close the event. Kedang is played between vocal, meanwhile violin is accompanying vocal. In nonformal situation such as in doing fishing, penandong beats the robin (canoe) instead of kedang. Generally, the nandong performance refers to the meaning, value, and norm of Islamic religion.

For the context, as a song, nandong can be represented in formal, nonformal and impromptu situation. In formal situation, nandong is framing by the main event like in wedding party. In nonformal situation nandong is sung based on the knowledge or memory the performer and to entertain himself and/or the audience around them while working. In impromptu situation, nandong is sung to inform about the nandong itself. It is usually because the request of the audience(s).

The meaning, value, and norm of nandong deals with Simeuluenese character and behaviour toward their local wisdom. One of indigenous knowledge that used in communication is nandong. Nandong as an oral tradition is shared and transmitted orally. The way to perform the mode to perform is essential part to study and to describe. Finnegan (2005: 12) stated that new performance begins with the interesting to the different (unique) retorically and esthetically in delivering the message in detail from the performer to the audiences. The idea is not only in context, but more to the essential of performance. In his other book, Finnegan (2015: 4) stated that the point of a speech event is not in written text, but more in its performance. Performance conveyed setting, delivering process and not only account the performer, but also the entire participant. Simeuluenese do nandong because they assume nandong as their responsibility to advise, share their experience and teach the generation about how to argue in their society. Sibarani (2018: 42) stated that local wisdom is indigenous knowledge or local genius of a sociaety derived from to make peace and improve the community welfare. Local wisdom can be local knowledge, local skill, local intelligence, local resources, local social process, local norms and local customs. Substantially, local wisdom is the values and cultural norms to organize the social life. The values and norms that are believed to be true become the reference for the daily behaviour of the local people.

\section{CONCLUSION}

The formula of nandong performance is related to verbal and nonverbal communication. The performance of nandong refers to advice. Advice occurs in imperative, invitation, and satire. The character of Simeuluenese is represented in nandong as one of their oral tradition. Advice refers to their character as moslem that living is loss without advice (telling something good) to the others. The meaning of andong performance has reference to advice both penandong and audience, to share stories toward behavioral managing and to share the knowledge in the core of Simeulunese local wisdom.

\section{REFERENCES}

- Bauman, R and Briggs, C. Poetics and Performance as Critical Perspectives on Language and Social Life. Annual Review of Anthropology, Vol. 19 (1990), pp. 59-88.

- Crowley T and Bowern, C. 2010. An Introduction to Historical Linguistic: 4th Edition. Oxford: University Press.

- Duranti, A. 1997. Linguistic Anthropology. Cambridge: Cambridge University Press. 
- Finnegan, R. 2005. Oral Traditions and the Verbal Arts. London: Routledge.

- Finnegan, R. 2015. Where is language? An Anthropologist's Questions on Language, Literature and Performance. London: Bloomsburry Academic.

- Honko, L. 2000. Textualization of Oral Epics. Berlin: Mouton de Gruyter.

- Lubis, T dan Abus, A.F. Tutur Nandong dalam Masyarakat Simeulue. KOLITA 15 (631-635). Pusat Kajian Bahasa dan Budaya Universitas Katolik Indonesia Atma Jaya. 2017.

How to cite this article: Lubis T, Sibarani R, Lubis S et.al. The performance of Nandong in Simeulue Island. International Journal of Research and Review. 2018; 5(12):283-289.
- Seyfeddinipur, M and Gullberg, M. 2014. From Gesture in Conversation to Visible Action as Utterance. Amsterdam/ Philadelphia: John Benjamin Publishing Company.

- Sibarani, R. Batak Toba Society's local wisdom of mutual cooperation in Toba Lake area: a linguistic anthropology study. International Journal of Human Rights in Healthcare, vol.11 (2018) Issue: 1,pp.40-55.

$* * * * * *$ 